\title{
The Challenge of Motivation in e-Learning: Role of Anxiety
}

\author{
Raafat George Saadé, Dennis Kira, and Fassil Nebebe \\ Department of Decision Sciences and MIS, John Molson School \\ of Business, Concordia University, Montreal, Quebec, Canada
}

\author{
raafat.saade@gmail.com; dkira@jmsb.concordia.ca; \\ fnebebe@jmsb.concordia.ca
}

\begin{abstract}
Anxiety, an emotional state, in elearning affects student's performance beyond the technophobic state, due to the fact that there is more at stake in elearning. These anxieties not only occur with the online course content interaction, but also in terms of productivity, learning risk, social relationships, and overall well-being. In this study, we select intrinsic motivation as an outcome that is influenced by challenge and mediated by anxiety. 565 students participated in this study showing significant influence of challenge and anxiety on intrinsic motivation. However, anxiety did not mediate the influence of challenge on intrinsic motivation. The results were discussed and recommendations for future research are presented.
\end{abstract}

Keywords: e-Learning; Anxiety; Intrinsic Motivation; Challenge

\section{Introduction}

Following a fully online course may have unpleasant side effects, which may include strong, negative emotional states that arise not only during the semester but even before, when the idea of not having classroom interaction with the professor. Frustration, confusion, anger, anxiety, and similar emotional states can affect not only the online course content interaction, but also productivity, learning, social relationships, and overall well-being. These negative emotional scales will be treated here-in as general anxiety towards e-learning environments.

There are a number of related definitions explaining what anxiety is: Leso and Peck (1992) define computer anxiety "as a feeling of being fearful or apprehensive when using or considering the use of a computer."

Evidently, factors such as the context in which an individual was first introduced to the computer (Brosnan, 1998a, 1998b; Rosen \& Weil, 1995), past failure and successes with hardware or software, and the current tasks being attempted, including the use of a new computer application

Material published as part of this publication, either on-line or in print, is copyrighted by the Informing Science Institute. Permission to make digital or paper copy of part or all of these works for personal or classroom use is granted without fee provided that the copies are not made or distributed for profit or commercial advantage AND that copies 1) bear this notice in full and 2) give the full citation on the first page. It is permissible to abstract these works so long as credit is given. To copy in all other cases or to republish or to post on a server or to redistribute to lists requires specific permission and payment of a fee. Contact Publisher@,InformingScience.org to request redistribution permission. and/or learning management system (Saadé \& Otrakji, 2007, Saadé, Buyukkurt, \& Alkhori, 2011), are all determinants of the state and type of anxiety the individual is experiencing. Researchers have attempted to predict the students that will experience computer anxiety by identifying factors that correlate with its occurrence such as attitudes (Ayersman, \& Liu, 1996, Saadé \& Kira, 2007, Saadé et al., 2008). There are three types of 
anxieties: Trait anxiety defined as a general pervasive anxiety that is experienced by a person over the entire range of life experience (Howard \& Smith, 1986). State anxiety is experienced as anxiety that fluctuates over time and arises to a responsive situation. Concept-specific anxiety is the range between the trait and state anxieties. It is an anxiety that is associated with a specific situation. Therefore, in this study we adopt elearning anxiety to be a concept-specific anxiety because it is a feeling that is associated with a student's interaction with an LMS where the stakes (course grade) are high (Oetting, 1983).

Anxiety can be viewed as a result of the beliefs a student may have, rather than an antecedent to those beliefs. For example, one could presume that a student who has a belief that s/he will experience problems (technology related, self directed learning, new environment, no face to face access to teacher, etc...) while following an online course has anxiety; as a result of the anxiety, $\mathrm{s} /$ he will be paranoid about computer problems while doing the online test, not spend enough time reading instructions on how to succeed in this course and find him/her-self isolated with no peer support whatsoever. The belief leads to fear, which leads to the behavior of paranoia, thereby causing the student to under-perform.

\section{Research Hypotheses}

In past elearning studies, the most common forum was related to the overall experience that students have had with an ecourse or the elearning environment. In general, findings tend to be indicative of a mixed set of experiences where a positive attitude toward computers is associated with better elearning experience.

Students taking e-learning courses were found to react on usability problems with fairly strong emotions. Scull (1999) found that students experienced higher levels of anxiety when they were under time or goal pressures, or when the technology failed or somehow malfunctioned. When something went wrong, this affected the emotional state of the students, leading to panic and anxiety. The study also showed that despite deadlines and equipment failure, many students were able to develop strategies that can reduce their computer anxiety.

In the same vein, Sheeson (2005) found that computer confidence had significant effects on user perception of task complexity. At the same time the effects of computer liking were found to be minimal at various task levels. In other words, this indicates that increasing computer experience may help reduce computer anxiety.

Students' performance in e-learning is affected by the way they react on the problems arising from the LMS pedagogy and technique. The positively reacting students are more equipped to overcome challenges and anxieties than the negatively reacting and thinking ones (Juutinen,and Saariluoma 2010). The students who manage to keep their attitude and thinking positive despite the setback in studying are more likely to be able to finish their courses with positive experiences.

Based on the brief latter discussion, we identified for this study, attitudes, challenge, intrinsic motivation and anxiety as the 4 primary dimensions that can contribute to the body of knowledge as it relates to emotions and elearning. More specifically, we investigate how anxiety can impact the relationship between challenge and intrinsic motivation. Specifically we make the following hypotheses shown in figures 1 and 2. 
H1: Challenge has a significant positive effect on students' intrinsic motivation is using LMS.

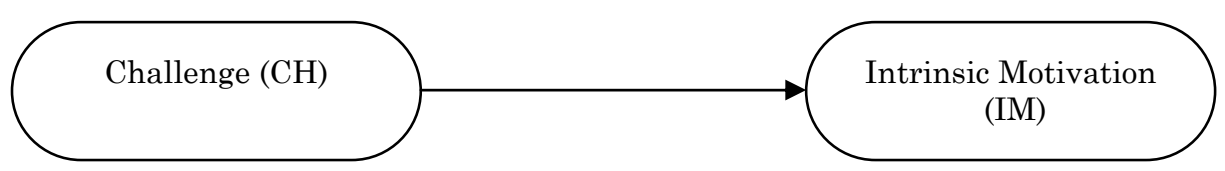

Fig.1. Effect of Challenge on Intrinsic Motivation

H2a: Anxiety significantly mediates the effect of challenge on intrinsic motivation in elearning.

$\mathrm{H} 2 \mathrm{~b}$ : Anxiety significantly mediates the effect of challenge on intrinsic motivation in elearning.

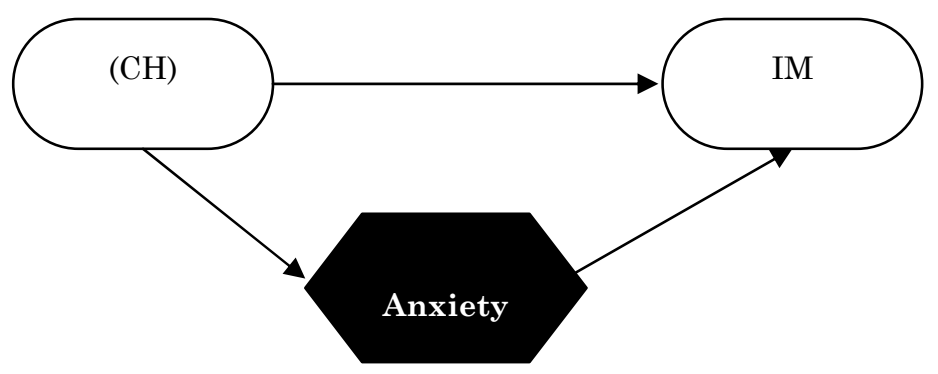

Fig.2. Mediation of anxiety

\section{Results \& Analysis of Findings}

\section{The Study}

The study was conducted in an undergraduate online course spanning two semesters, using the university learning management system (LMS) as the target system (this system was built inhouse). Throughout the semester, students in an introductory Fundamentals of Information Technology Course (FIT) at a major university in Canada used the LMS for all course requirements. The course included static content, media, interactive tools and support tools to help students understand course topics via activities such as practicing multiple choice and true or false questions, peer support discussions, online assignments, cases and so on. The learning tool is web based and can be accessed using any web browser on any platform. The LMS monitored the students' activities by storing the time spent on the system, the chapters practiced, and scores.

At the end of the semester, a survey instrument was administered. Five hundred and sixty five (565) students participated in this study. Items (presented in table 1) used to measure the constructs were adopted from prior research work namely Davis (1989) and Venkatesh (1999). The items were validated in a pilot study and some wording was changed to account for the context of using learning tools. All items were measured using a five-point Likert-type scale with anchors from "Strongly disagree" to "Strongly agree". 
Table1. Measures of study variables.

\begin{tabular}{|c|c|c|c|c|c|}
\hline Challenge & $\begin{array}{l}\text { Strongly } \\
\text { Disagree }\end{array}$ & $\begin{array}{l}\text { Somewhat } \\
\text { Disagree }\end{array}$ & Neutral & $\begin{array}{c}\text { Somewhat } \\
\text { Agree }\end{array}$ & $\begin{array}{c}\text { Strongly } \\
\text { Agree }\end{array}$ \\
\hline I feel that using the ILS would challenge me. & $\mathrm{O}$ & $\mathrm{O}$ & $\mathrm{O}$ & $\mathrm{O}$ & $\mathrm{O}$ \\
\hline $\begin{array}{l}\text { I feel that using the ILS would challenge me to } \\
\text { perform to the best of my abilities. }\end{array}$ & 0 & $\mathrm{O}$ & 0 & 0 & 0 \\
\hline $\begin{array}{l}\text { The ILS would provide me with a good test of my } \\
\text { skills. }\end{array}$ & $\mathrm{O}$ & $\mathrm{O}$ & $\mathrm{O}$ & $\mathrm{O}$ & $\mathrm{O}$ \\
\hline $\begin{array}{l}\text { Using the ILS would stretch my capabilities to my } \\
\text { limits. }\end{array}$ & $\mathrm{O}$ & $\mathrm{O}$ & $\mathrm{O}$ & $\mathrm{O}$ & O \\
\hline Attitude & $\begin{array}{l}\text { Strongly } \\
\text { Disagree }\end{array}$ & $\begin{array}{l}\text { Somewhat } \\
\text { Disagree }\end{array}$ & Neutral & $\begin{array}{c}\text { Somewhat } \\
\text { Agree }\end{array}$ & $\begin{array}{c}\text { Strongly } \\
\text { Agree }\end{array}$ \\
\hline $\begin{array}{l}\text { Using web-based learning systems in the } \\
\text { Comm301 course would be a good idea. }\end{array}$ & O & $\mathrm{O}$ & O & O & O \\
\hline $\begin{array}{l}\text { Using web-based learning systems in the } \\
\text { Comm301 course would be unpleasant. (R) }\end{array}$ & $\mathrm{O}$ & 0 & $\mathrm{O}$ & $\mathrm{O}$ & $\mathrm{O}$ \\
\hline $\begin{array}{l}\text { Using web-based learning systems would be bene- } \\
\text { ficial to me in the Comm } 301 \text { course. }\end{array}$ & $\mathrm{O}$ & $\mathrm{O}$ & $\mathrm{O}$ & $\mathrm{O}$ & $\mathrm{O}$ \\
\hline Intrinsic Motivation & $\begin{array}{l}\text { Strongly } \\
\text { Disagree }\end{array}$ & $\begin{array}{l}\text { Somewhat } \\
\text { Disagree }\end{array}$ & Neutral & $\begin{array}{c}\text { Somewhat } \\
\text { Agree }\end{array}$ & $\begin{array}{c}\text { Strongly } \\
\text { Agree }\end{array}$ \\
\hline I find that the ILS would be enjoyable. & $\mathrm{O}$ & 0 & 0 & $\mathrm{O}$ & $\mathrm{O}$ \\
\hline $\begin{array}{l}\text { The actual process of using the ILS seems to be } \\
\text { pleasant. }\end{array}$ & $\mathrm{O}$ & $\mathrm{O}$ & $\mathrm{O}$ & $\mathrm{O}$ & $\mathrm{O}$ \\
\hline I think I would have fun using the ILS. & $\mathrm{O}$ & $\mathrm{O}$ & $\mathrm{O}$ & $\mathrm{O}$ & $\mathrm{O}$ \\
\hline Anxiety & $\begin{array}{l}\text { Strongly } \\
\text { Disagree }\end{array}$ & $\begin{array}{l}\text { Somewhat } \\
\text { Disagree }\end{array}$ & Neutral & $\begin{array}{c}\text { Somewhat } \\
\text { Agree }\end{array}$ & $\begin{array}{c}\text { Strongly } \\
\text { Agree }\end{array}$ \\
\hline I feel apprehensive about using computers. & $\mathrm{O}$ & $\mathrm{O}$ & $\mathrm{O}$ & $\mathrm{O}$ & $\mathrm{O}$ \\
\hline $\begin{array}{l}\text { It scares me to think that I could cause the com- } \\
\text { puter to destroy a large amount of information by } \\
\text { hitting the wrong key. }\end{array}$ & $\mathrm{O}$ & $\mathrm{O}$ & $\mathrm{O}$ & $\mathrm{O}$ & $\mathrm{O}$ \\
\hline $\begin{array}{l}\text { I hesitate to use a computer for fear of making } \\
\text { mistakes I cannot correct. }\end{array}$ & $\mathrm{O}$ & $\mathrm{O}$ & $\mathrm{O}$ & $\mathrm{O}$ & $\mathrm{O}$ \\
\hline Computers are somewhat intimidating to me. & $\mathrm{O}$ & 0 & 0 & $\mathrm{O}$ & $\mathrm{O}$ \\
\hline
\end{tabular}

\section{Exploratory Factor Analysis}

The purpose of exploratory factor analysis (EFA) is to identify the number of factors and the structure. The exploratory factor analysis identifies 4 factors that explain $62.98 \%$ of the total variance. The correlations are complex, since the variables load on multiple factors. In order to improve interpretability, we restrict the factor loadings to be greater than 0.7. From the EFA analysis, we identify the following factors: 
Factor 1: ATT, IM (attitude, intrinsic motivation)

Factor 2: ANX (affect, anxiety)

Factor 3: $\mathrm{CH}$ (challenge)

Our key interest is in the relationship between $\mathrm{CH}$ and IM, and the impact of ANX on that relationship. The final measurement model with loadings greater than 0.7 are as follows:

$\mathrm{CH}: \mathrm{CH} 1(0.760)$ and $\mathrm{CH} 2(0.763)$

IM: ATT1 (0.785), ATT2 (0.807), I1 (0.744), IM1 (0.730)

ANX: ANX3 (0.846) and ANX4 (0.772)

\section{Structural Model}

The proposed mediation hypotheses are often tested by using a statistical technique suggested by Baron and Kenny (1986). Mediation is considered to be established based on the following criteria: (1) A significant relationship exists between the independent variable and the dependent variable; (2) a significant relationship exists between the independent variable and the presumed mediator; and (3) in the presence of a significant relationship, the previous significant relationship between the independent variable and the dependent variable is no longer significant or the strength of the relationship is significantly decreased. Figure 3 presents the results of the structural model.

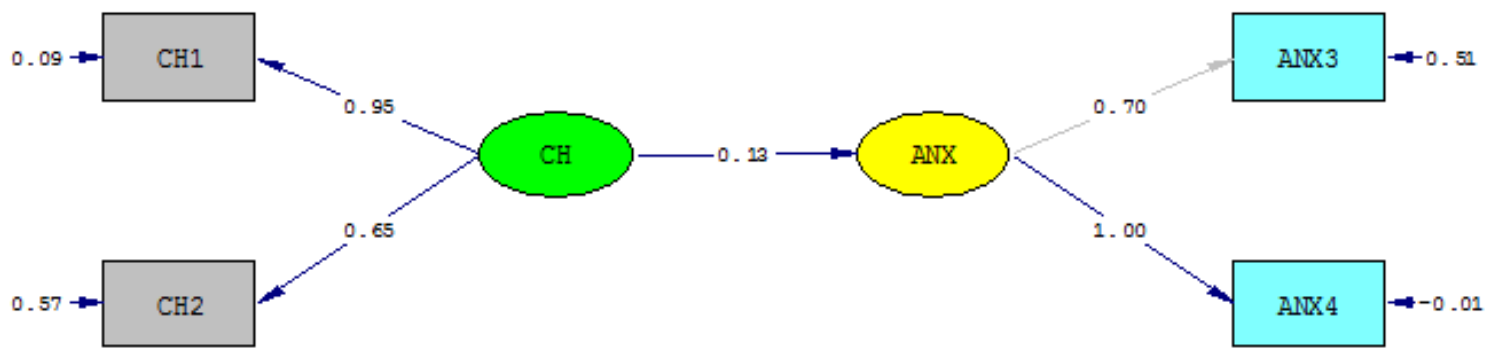

Chi-Square=1.62, df=1, P-value $=0.20376, \mathrm{RMSEA}=0.033$ 


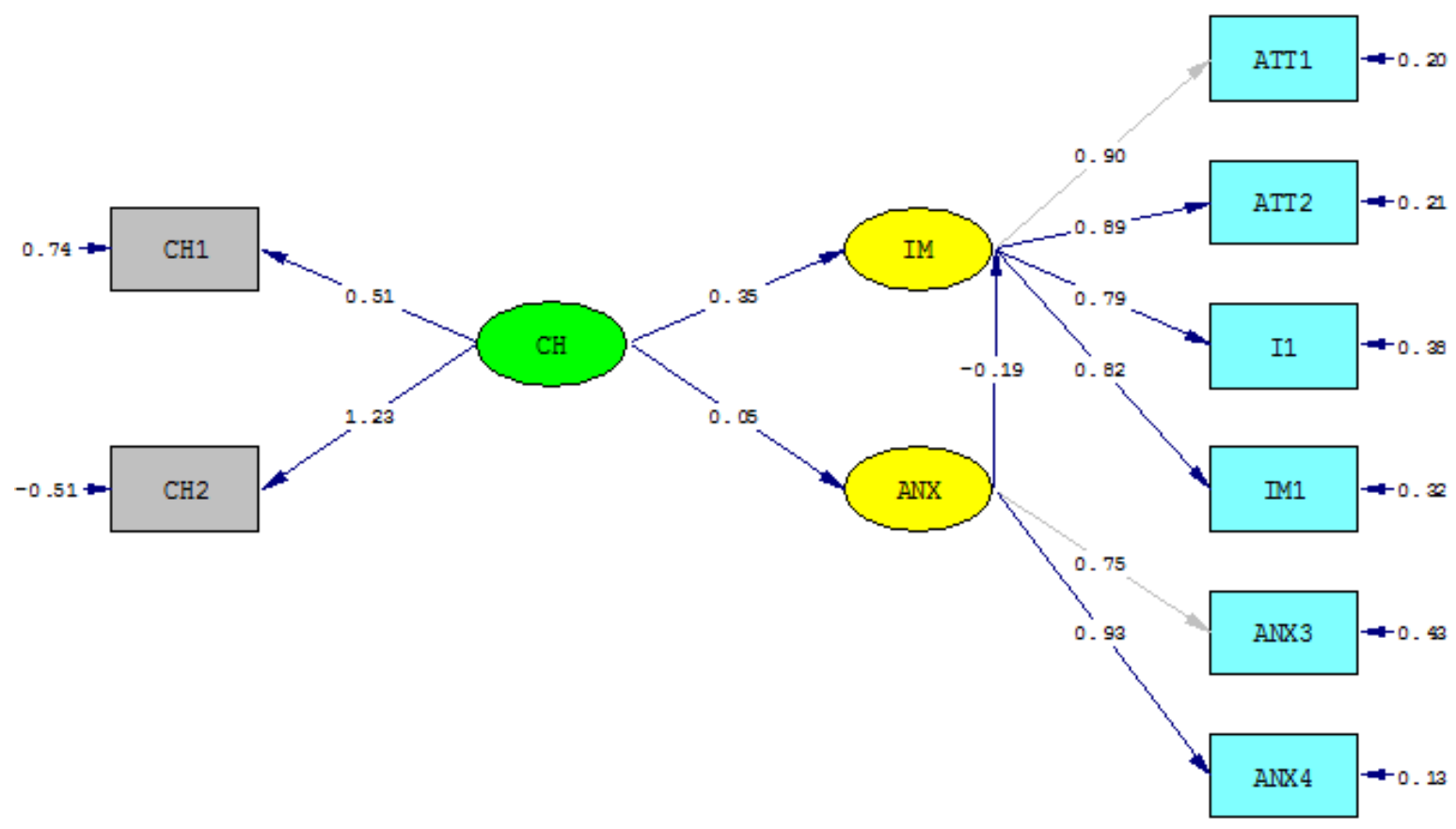

Chi-Square $=67.14, \mathrm{df}=17, \mathrm{p}-\mathrm{value}=0.00000, \mathrm{RMSEA}=0.072$

Fig.3. Mediation of anxiety

\section{Goodness of Fit Statistics}

Degrees of Freedom $=17$

Normal Theory Weighted Least Squares Chi-Square $=67.14(\mathrm{P}=0.00)$

Root Mean Square Error of Approximation (RMSEA) $=0.072$

P-Value for Test of Close Fit $($ RMSEA $<0.05)=0.020$

Non-Normed Fit Index $(\mathrm{NNFI})=0.97$

Comparative Fit Index $(\mathrm{CFI})=0.98$

Goodness of Fit Index (GFI) $=0.97$

Adjusted Goodness of Fit Index (AGFI) $=0.94$

We assess the indirect effect from $\mathrm{CH} \rightarrow \mathrm{ANX} \rightarrow \mathrm{IM}$ : The direct effect of $\mathrm{CH}$ on $\mathrm{IM}(0.35, \mathrm{t}-$ value 6.62$)$ is significant at $5 \%$. The indirect effect of $\mathrm{CH}$ on ANX $(0.05$, t-value 1.48$)$ is significant only at $10 \%$, while the effect of ANX on IM (-0.19, t-value -4.45$)$ is significant at $5 \%$. Next, we assess the indirect from $\mathrm{CH} \rightarrow \mathrm{IM} \rightarrow$ ANX: The direct effect of $\mathrm{CH}$ on ANX $(0.13$, t-value $2.89)$ is significant at $5 \%$, and the indirect effects of $\mathrm{CH}$ on IM $(0.34$, t-value 6.53$)$ and IM on ANX (-0.22, t-value -3.71) are both significant at 5\%. The sequential chi-square test indicates a significant fit over the previous model without the indirect effect, as the chi-square difference is $83.53-67.14=16.39, \mathrm{df}=1$, significant at $1 \%$.

Following the same methodology but with IM as the mediator to the $\mathrm{CH}-\mathrm{ANX}$ relationship, we find that the indirect effect of $\mathrm{CH} \rightarrow \mathrm{IM} \rightarrow \mathrm{ANX}$ is a stronger model. 


\section{Discussion and Concluding Remarks}

Is it possible that elearning can achieve $100 \%$ effectiveness? This value proposition implies that once the learning goals for a course are specified, the elearning paradigm can provide the environment whereby all students can achieve a grade of A. To the first author of this article, this is the elearning dream. Technology today provides us with all the tools to realize this dream.

This study shows that attitudes and anxiety cannot be measured separately due to the idea that beliefs prior to taking an online course introduces negative affect into the learning experience. At the same time it seems that an increase in anxiety reduces intrinsic motivation, which is a form of enjoyment while learning. Research has shown that students learn best when they are enjoying the online activity - a form of flow experienced during online gaming.

We therefore believe that the direction of research should be towards building elearning environments that support flow where a balance between challenge and motivation is achieved and adapted to the different students, while mitigating anxiety.

\section{Reference}

Ayersman, D. J., \& Liu, M. (1996). Reviewing the research on hypermedia-Based learning. Journal of Research on Computing Education, 4(24), 500-525.

Baron, M. R., \& Kenny, D. (1986). The moderator-mediator variable distinction in social psychological research: Conceptual, strategic, and statistical considerations. Journal of Personality and Social Psychology, 51(6), 1173-1182.

Brosnan, M. J. (1998a). Technophobia: The psychological impact of information technology. New York: Routledge.

Brosnan, M. J. (1998b). The impact of computer anxiety and self-efficacy upon performance. Journal of Computer Assisted Learning, 14, 223-234.

Davis, F. D. (1989). Perceived usefulness, perceived ease of use, and user acceptance of information technology. MIS Quarterly, 13(3), 319-339.

Howard, S. G., \& Smith, D. R. (1986). Computer anxiety in management: myth or reality? Communications of the ACM, 29(7), 611-615.

Juutinen, S., \& Saariluoma, P. (2010). Emotional obstacles for e-learning - A user psychological analysis. European Journal of Open, Distance and E-learning.

Leso, T., \& Peck, K. L. (1992). Computer anxiety and different types of computer courses. Journal of Educational Computing Research, 8(4), 469-478.

Oetting, E. R. (1983). Oetting's Computer Anxiety Scale (COMPAS). Ft. Collins, CO: Rocky Mountain Behavioral Science Institute.

Rosen, L. D., \& Weil, M. M. (1995). Computer anxiety: A cross-cultural comparison of university students in ten countries. Computers in Human Behavior, 11(1), 45-64.

Saadé, R. G., Buyukkurt, M. D., Alkhori, C. (2011). Technology mediated learning: Observations in two technologies. Issues in Informing Science \& Information Technology, 8, 395-408.

Saadé, R. G., \& Kira, D. (2007). Mediating the impact of technology usage on perceived ease of use by anxiety. Computers \& Education, 49(4), 1189-1204.

Saadé, R. G., \& Kira, D. (2009). Computer anxiety in e-learning: The Effect of Computer Self-Efficacy Journal of Information Technology Education, 8, 177-191. Retrieved from http://www.jite.org/documents/Vol8/JITEv8p177-191Saade724.pdf

Saadé, R. G., \& Otrakji, C. (2007). First impressions last a lifetime: Effect of disorientation and cognitive load. Computers in Human Behavior, 23(1), 525-535. 
Scull, C. A. (1999). Computer anxiety at a graduate computer center: Computer factors, support, and situational pressures. Computers in Human Behavior, 15(2), 213-226.

Sheeson, E. C. (2005). Computer anxiety and perception of task complexity in learning programmingrelated skills. Computers in Human Behavior, 21(5), 713-728.

Venkatesh, V. (1999). Creation of favorable user perceptions: Exploring the role of intrinsic motivation. MIS Quarterly, 23(2), 239-260.

Weil, M. M., \& Rosen, L. D. (1995). The psychological impact of technology from a global perspective - A study of technological sophistication and technophobia in university students from 23 countries. Computers in Human Behavior, 11(1), 95-133.

\section{Biographies}

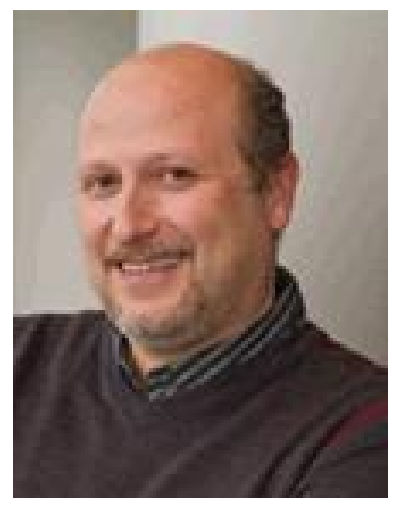

Dr. Raafat George Saade has been teaching in the faculty since 1998. He obtained his Ph.D. in 1995 (Concordia University) after which he received the Canadian National Research Council postdoctoral fellowship, which he completed at McGill University in Montreal. Dr. Saade has published in journals such as Information \& Management, Decision Sciences, and Expert Systems with Applications. His research interests include the development and assessment of information systems, and the supply chain of digital information products.

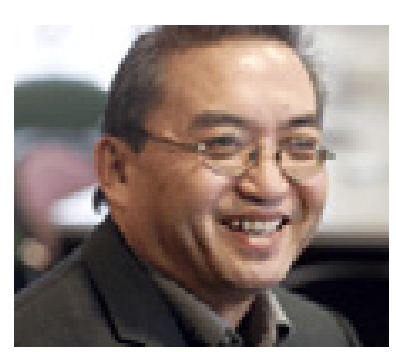

Dr. Dennis Kira is an associate professor at the Decision Sciences MIS department, John Molson School of Business, Concordia University, Canada. He has been with the Faculty since 1983. He obtained his Ph.D. from University of British Columbia. Dr. Kira teaches System design, decision support systems, data management, data mining, Internet related programming, and e-commerce His research activities include Ecommerce, web design, distance learning, decision making under uncertainty, neural networks, machine learning, and financial modeling. Dr. Kira has published in IEEE, ORQ and management science among other journals.

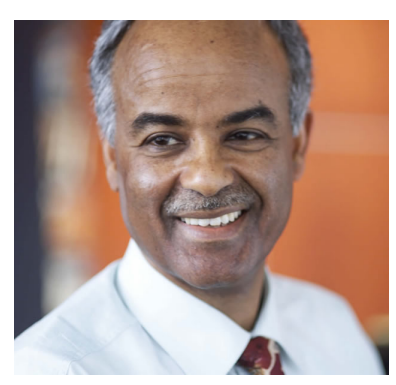

Fassil Nebebe (Ph.D., P.Stat.) is a Professor and Chair of the Department of Decision Sciences \& MIS of the John Molson School of Business, Concordia University, Montreal, Canada. His research focuses on statistical methods using Bayesian modeling and has made contributions with results published in different areas such as small area estimation, the bootstrap, Gibbs sampling, statistical computing, regression models and simulated MLE. He has served as Managing Editor of Liaison - The Newsletter of the Statistical Society of Canada (2004 - 2007), and as President of the Statistical Society of Montreal (2002/2003). He is the founding President of SSENA (1999-2002). 